\title{
Egy különleges pancreaselváltozás: kevert differenciációjú nodularitás és diffúz szigetsejtes hyperplasia
}

\author{
Zalatnai Attila dr. ${ }^{1}$. Tőke Judit dr. ${ }^{2}$. Huszty Gergely dr. ${ }^{3}$ \\ Müllner Katalin dr. ${ }^{4}$. Tóth Miklós dr. ${ }^{2}$ \\ ${ }^{1}$ Semmelweis Egyetem, Általános Orvostudományi Kar, I. Patológiai és Kísérleti Rákkutató Intézet, Budapest \\ ${ }^{2}$ Semmelweis Egyetem, Általános Orvostudományi Kar, Belgyógyászati és Onkológiai Klinika, \\ Endokrinológiai Tanszék, ENETS Kiválósági Központ, Budapest \\ ${ }^{3}$ Semmelweis Egyetem, Általános Orvostudományi Kar, Transzplantációs és Sebészeti Klinika, Budapest \\ ${ }^{4}$ Semmelweis Egyetem, Általános Orvostudományi Kar, I. Sebészeti Klinika, Budapest
}

\begin{abstract}
A szerzők egy különleges pancreaselváltozás esetét ismertetik, melyben az acinusok neuroendokrin jellegű transzformációja diffúz, atípusos megjelenésú szigetsejtes hyperplasiával társult, valamint a pancreas mindhárom sejtvonalát (acinaris, ductalis, insularis) tartalmazó nodulusok képződtek. A komplex megjelenés ellenére a kórfolyamat nem járt endokrin tünetekkel. Esetünkben a kiváltó ok hátterében a struktúrák kóros progenitorsejt-differenciációja állhatott. Az irodalomban ilyen közlés eddig nem ismert.
\end{abstract}

Orv Hetil. 2021 ; $162(6): 227-232$.

Kulcsszavak: pancreas, differenciációs zavar, progenitorsejtek

\section{A peculiar pancreatic lesion: nodular foci of trilineage differentiation and diffuse islet cell hyperplasia}

The authors present a case of a peculiar pancreatic lesion, in which the neuroendocrine transformation of the acini was associated with a diffuse, atypical insular hyperplasia, and micronodules exhibiting trilineage differentiation. Despite the complex alteration, no endocrine symptoms were noted. The case may represent the result of an abnormal pancreatic differentiation raising the possibility of reprogramming of the progenitor cells. To the best of our knowledge, this is the first report of such a lesion in the literature.

Keywords: pancreas, disturbance of differentiation, progenitor cells

Zalatnai A, Tóke J, Huszty G, Müllner K, Tóth M. [A peculiar pancreatic lesion: nodular foci of trilineage differentiation and diffuse islet cell hyperplasia]. Orv Hetil. 2021; 162(6): 227-232.

(Beérkezett: 2020. július 11.; elfogadva: 2020. augusztus 16.)

\section{Rövidítések}

5-HIAA $=$ (5-hydroxyindoleacetic acid $)$-hidroxi-indolecetsav; $\mathrm{CT}=$ (computed tomography) számítógépes tomográfia; MiNEN $=($ mixed neuroendocrine + non-neuroendocrine tumors) kevert neuroendokrin + nem neuroendokrin tumorok; STAT3 $=($ signal transducer and activator of transcription 3$)$ jelátvivő és transzkripciós aktivátor-3
A hasnyálmirigyet felépítő struktúrák az esetek messze túlnyomó többségében valamelyik sejtvonal (ductalis, acinaris vagy szigetsejtes) jellegzetességeit mutatják, mind morfológiailag, mind immunhisztokémiai vagy molekuláris szempontból. In vitro kísérletekben azonban bizonyítékok vannak a különböző irányban elkötelezett sejtvonalak plaszticitására, és bizonyos körülmények 
között (például regeneráció kapcsán) felnőttpancreasban is megjelenhet transzdifferenciáció. Ez megnyilvánulhat akár különböző hisztogenezisû́ elemek egyidejü jelenlétében, de akár májszövetirányú is lehet. Nem meglepő, hogy a daganatos elváltozások között, ritkán ugyan, de előfordulnak kevert exokrin és endokrin elemekből felépülő formák is, mivel a tumorképződésben lényeges momentum a sejtek/szövetek genetikai és epigenetikai instabilitása, valamint egyes inaktív génszakaszok újbóli, de szabályozatlan múködésbe lépése. Olyan eset nem ismert az irodalomban, amelyben komplex, nem daganatos jellegü, kevert exokrin-endokrin laesiók diffúzan érintenék a pancreas állományát. Esetünkben ilyen elváltozást találtunk.

\section{Esetismertetés}

A 46 éves obes nőbeteg távolabbi anamnézisében discopathia, pajzsmirigy follicularis adenoma eltávolítása, a jobb oldali mellékvesekéreg inaktív adenomája szerepel, valamint évek óta ismert a duodenalis fekélye. Néhány éve jelentkező epigastrialis fájdalom, időszakosan (heti 4-5 alkalommal) hasmenései, kipirulással járó rosszullétei említhetők, de kromogranin-A-, gasztrin- és 5-HIAAértékei a normáltartományon belül voltak, akárcsak a vércukorszintek $(5,4-5,7 \mathrm{mmol} / \mathrm{l})$, továbbá a pancreas exokrin múködését jellemző lipáz-, amilázértékek is. Gasztroduodenoszkópia során egy $0,5 \mathrm{~cm}$ átmérőjü, Gl-es besorolású neuroendokrin tumor került eltávolításra a duodenumból, mely immunhisztokémiai vizsgálattal gasztrinpozitívnak bizonyult, míg inzulin nem volt jelen. A kontrollvizsgálatok (CT, endoszkópos ultrahangvizsgálat) alkalmával ismételten submucosus, kb. 1 cm-es, endoszkóppal el nem távolítható duodenalis szövetszaporulat igazolódott, így a beteget limitált mútét tervével megoperáltuk. A beavatkozás során a tapintható duodenalis laesio mellett - váratlanul - a pancreas fejében is egy kb. $2 \mathrm{~cm}$-es, kissé körülírt, enyhén tömött területet észleltünk: ennek intraoperatív fagyasztott vizsgálata ugyancsak neuroendokrin tumorra utalt, ezért Whipple szerinti pancreatoduodenectomiát végeztünk. A perioperatív szakban pancreas anastomosis insufficientia lépett fel, ezért teljes pancreaseltávolítás vált szükségessé, splenectomiával. A kiterjesztett mútétet további súlyos szövődmények komplikálták: akut légúti distressz szindróma, pneumonia, akut veseelégtelenség, Clostridium difficile infekció, inficiált hasüri gyülemek, melyek három alkalommal evacuatióra szorultak, időszakos gyomorürülési zavar. Mindezeket közel 2 hónapos intenzív kezeléssel sikerült leküzdeni, és a továbbiakban a beteg további szoros diabetológiai kontroll alatt áll.

A duodenum bedomborodásának hátterében szövettanilag részben Brunner-mirigy-hyperplasia, részben az izomréteg erőteljes megvastagodása állt, de sem fekélyt, sem neuroendokrin tumor maradványát nem észleltük. A pancreas részletes feldolgozása során sem találtunk kö-

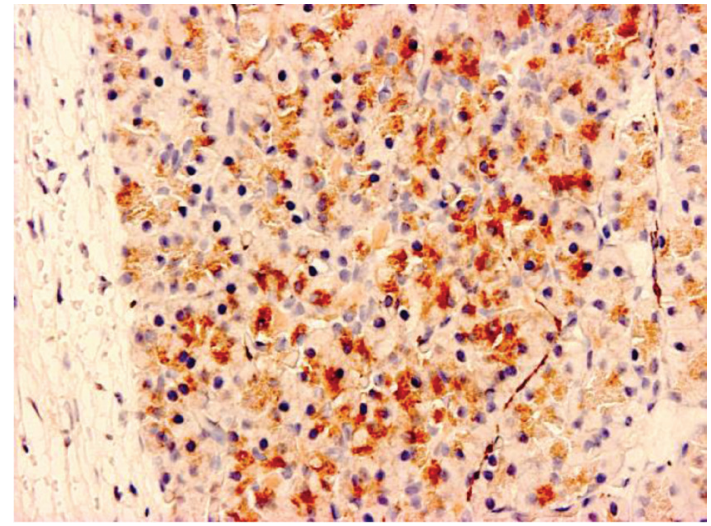

1. ábra | Szinaptofizinpozitivitás a pancreas acinusaiban $(400 \times)$
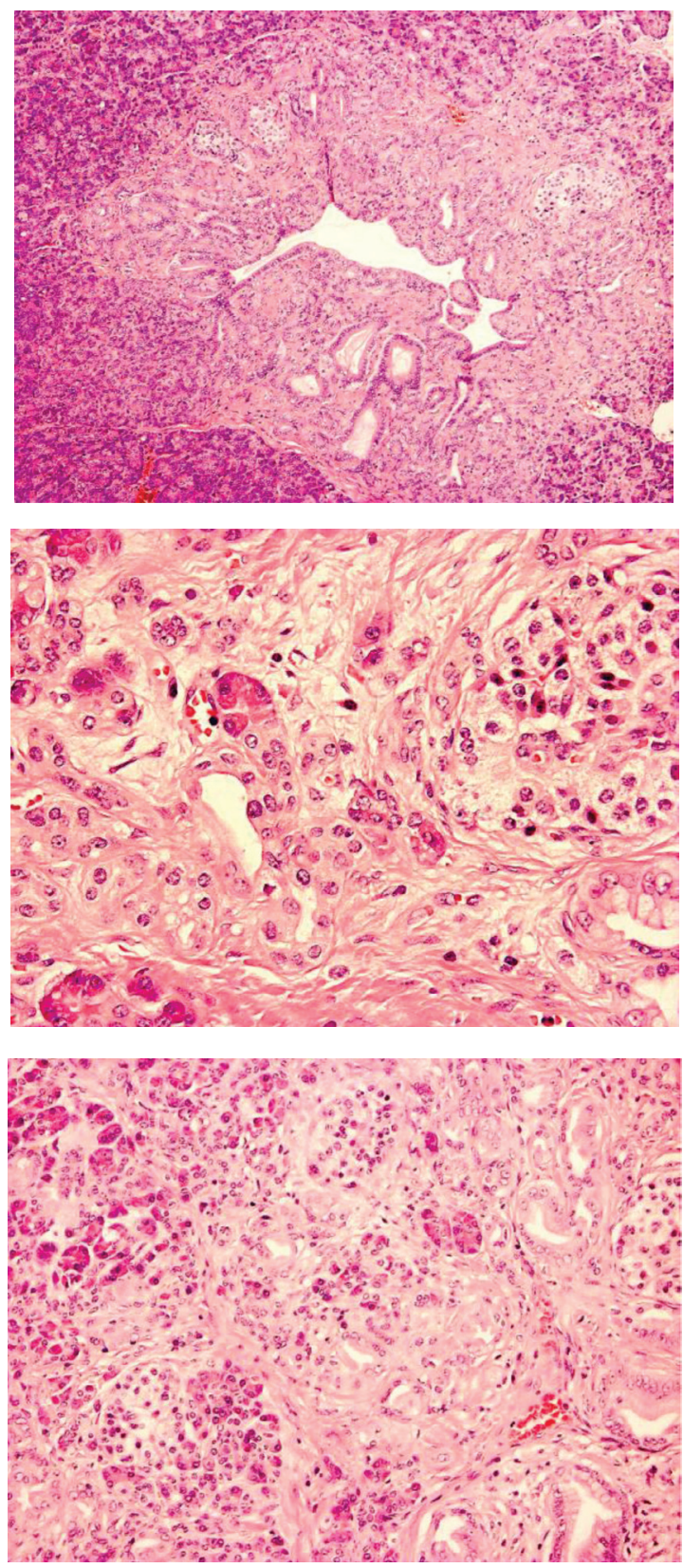

2-4. ábra |Acinusok, ductulusok és endokrin szigetek együtteséből felépüló gócok (100-200-400× 
rülírt daganatot, ellenben rendkívül szokatlan elváltozások kombinációjával találkoztunk.

1) A megőrzött struktúrájú acinusokban intenzív szinaptofizinpozitivitás mutatkozott, amely a fej-test-farok területén egyaránt kimutatható volt, különböző intenzitással (1. ábra).

2) A pancreas minden régiójában $2-3 \mathrm{~mm}$ átmérőjü gócok jelentek meg, melyekben egymással keveredve acinusok, ductulusok és szigetsejtek együttes kombinációja volt jelen (2-4. ábra).

3 ) Összehasonlítottuk a Langerhans-szigetek számbeli eltérését (kontrollként egészséges donorpancreast használva). Azonos nagyítás mellett a kontrollmintából 15, a beteg metszeteiből 20 látótérben meghatároztuk a szinaptofizinpozitív szigetek számát, ami jelentôs felszaporodást mutatott $(12,4 \pm 4,7$ a normálpancreasban észlelt 6,65 $\pm 2,5$ értékkel szemben) (5. ábra).

4. A felszaporodott Langerhans-szigetek mérete is nőtt a kontrollhoz képest $(269 \pm 67$ vs. $208 \pm 96 \mu \mathrm{m}$; $\mathrm{p}<0,01)$, valamint szabályos morfológiájuk mellett elágazódó vagy nyúlványos formák is bőven láthatók (6. ábra).

\section{Megbeszélés}

Esetünket a pancreasban zajló rendkívül szokatlan, komplex differenciációs folyamatok miatt ismertettük; ehhez hasonló közlést az irodalomban még nem találtunk. A szinaptofizin mint neuroendokrin marker a kis neuroszekréciós granulumok membránjában lokalizálódik, és mint ilyen, normálkörülmények között a pancreas acinusaiban nem jelenik meg. Ezt az esetünkben látható jelenséget acinaris neuroendokrin transzformációnak tarthatjuk. Ez a tulajdonság vezetett az intraoperatív fagyasztott metszetek „neuroendokrin tumor”-ként történő interpretálásához, mivel hasonló elváltozásról nem volt tudomásunk.

A folyamathoz emellett szerkezeti torzulással járó, diffúz szigetsejtes hyperplasia is társult. A Langerhans-szigetek hyperplasiája többnyire az egyes sejtalkotók (föleg a $\beta$-sejtek) jellegzetes hormontermelésével jár (nesidioblastosis), míg endokrin tünetek nélküli megnagyobbodásukat legtöbbször - mint reaktív elváltozást - krónikus, fibrotizáló pancreatitisben látni. Esetünkben egyik állapot sem állt fenn, a diffúzan megjelenő elváltozás megváltozott strukturális eltérést reprezentált, és fokozott Ki-67 proliferációs index is csak néhány szigetben volt jelen, de döntő többségükben 1\% körüli értéket adott.

A másik, jellegzetes elváltozás egy igen különleges differenciációs zavarban nyilvánult meg: a különböző szöveti struktúrák számos területen kevert nodularitás formájában jelentek meg, melyekben ductalis, acinaris és insularis elemek változó arányban keveredtek. A fenti elváltozások a pancreas egész területén jelen voltak, közel egyenletes eloszlásban.

E komplex folyamatok együttes kialakulása két elméleti lehetőséget vet fel. Egyfelől arra utalhat, hogy bizonyos körülmények között a már differenciálódott sejtvonalak visszanyerhetik az embrionális fejlődés fázisában meglévő képességeiket, és alternatív irányú fejlődésen mehetnek át. A másik lehetőség, hogy a pancreas ductu-

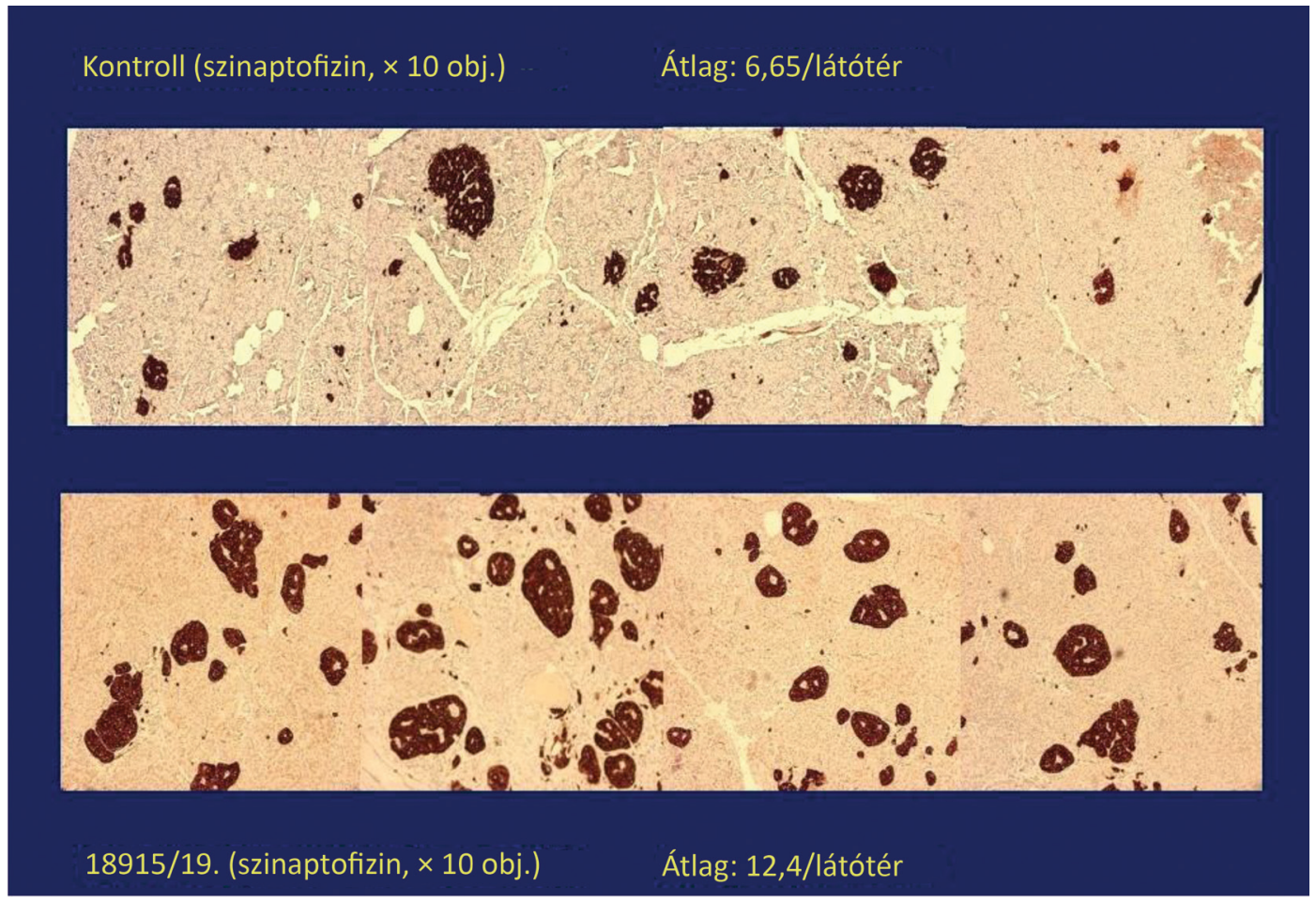




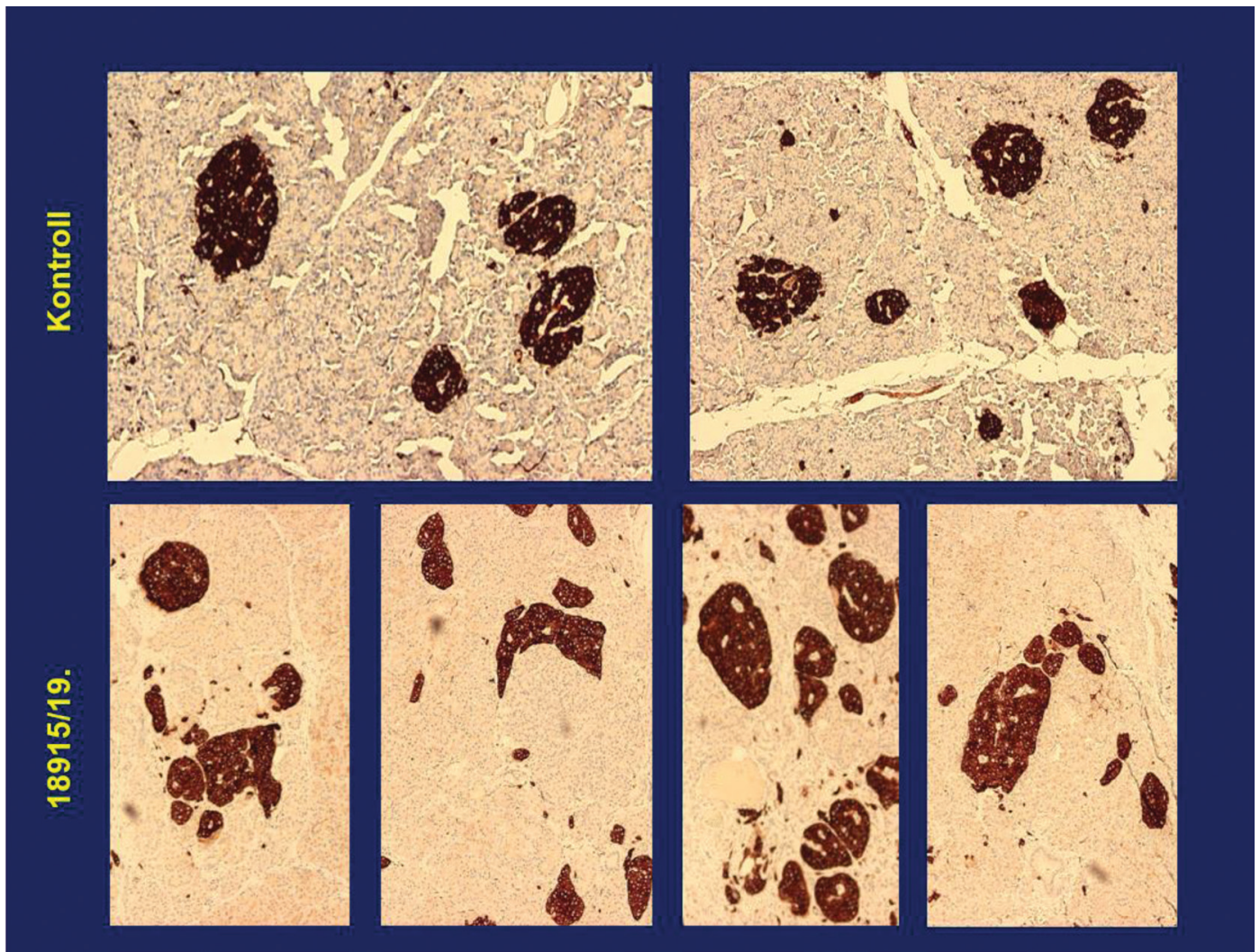

lusaiban felnőttkorban is megmaradó, de inaktív progenitorsejtek genetikai programjai valamilyen nem azonosított hatásra ismét aktiválódnak, és az embrionális életben látható, de szabályozatlanabb fejlődésen mennek át. E két, hipotetikus mechanizmus kiváltó okai egyelőre teljességgel ismeretlenek.

A pancreas multipotens progenitorsejtjei már az embrionális élet első-második hetében megjelennek, és néhány nap múlva tovább differenciálódnak ductalis, acina- ris és insularis progenitorsejtekké, ugyanakkor kis számban még napokig megmaradnak a multipotens progenitorok is (7. ábra). Az egyes irányban elkötelezett sejtcsoportok kialakulása rendkívül összetett folyamat: döntően számos transzkripciós faktor kaszkádszerű aktivitása a meghatározó, de a folyamatot jelentősen befolyásolják még a mesenchymalis stroma felől érkező parakrin szignálok is, melyek a szerv végső kialakulásának folyamatában végig hatnak, és ugyanúgy az erek endo-

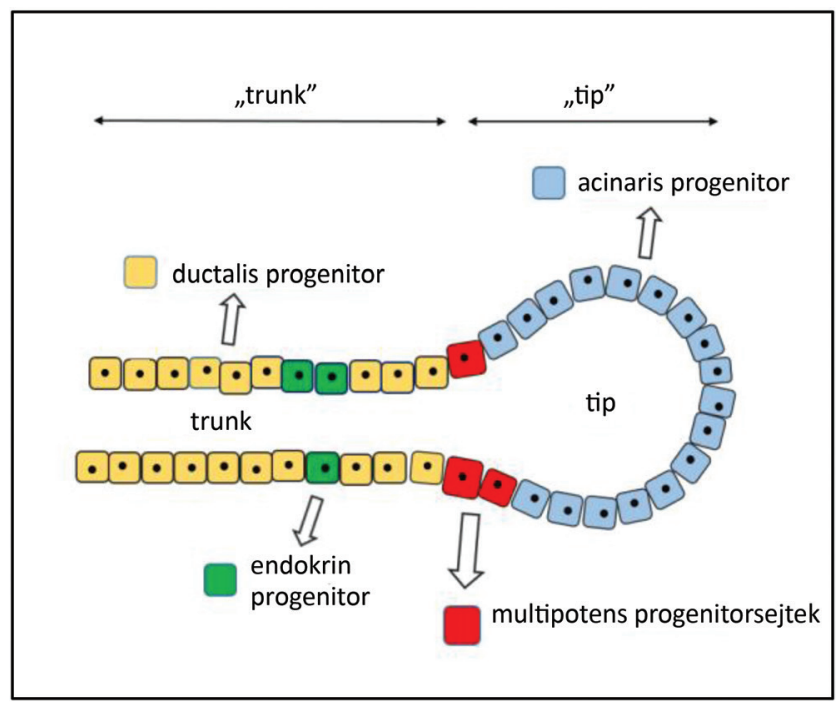

7. ábra

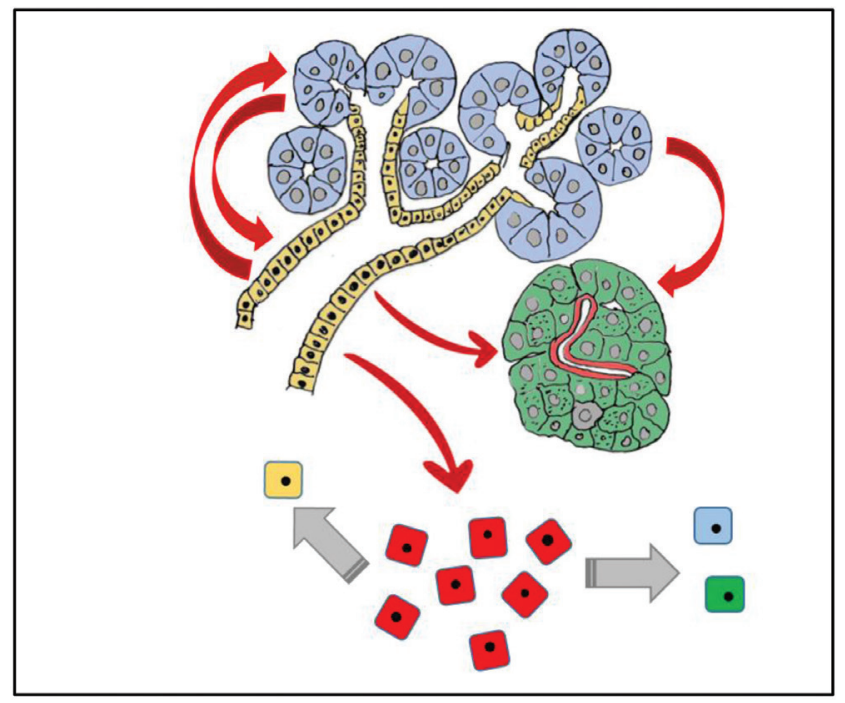

8. ábra

| Transzdifferenciálódási lehetőségek felnőttpancreasban 
theljéból érkező szolúbilis faktorok is [1]. A „tip” progenitorsejtjeiből az acinusok, míg a „trunk” elemeiből a ductusok/ductulusok, valamint a Langerhans-szigetek differenciálódnak. Bár az egyes szöveti struktúrák jellegzetesen elkülönülnek, jól meghatározott morfológiai/ funkcionális jellemzőkkel bírnak, nem feltétlenül megváltoztathatatlanok; bizonyos körülmények között fenotípusos plaszticitásuk is megfigyelhető (8. ábra). Kimutatták, hogy acinaris-insularis transzdifferenciáció jöhet létre például pancreasregeneráció során, de arra is van adat, hogy ez a folyamat kiindulhat ductalis sejtekből is (például subtotalis pancreaseltávolítás után). In vivo acinaris-ductalis átalakulás is kimutatható. Ezekben a folyamatokban többen az epithelialis-mesenchymalis átmenet fontosságát emelik ki, de továbbra is kérdéses, hogy az inaktív állapotban lévő progenitorsejtek a kulcsfontosságúak, vagy az intercalaris ductusok sejtjeiben történik dedifferenciálódás [2].

$\mathrm{Az}$ acinusok, ductulusok, insularis sejtek közötti kölcsönös transzdifferenciálódás molekuláris átprogramozódás ( „reprogramming”) eredménye, amely virális indukció vagy akár regenerációs tevékenység kapcsán ismételten bekapcsolja azokat a géneket, melyek a korai embrionális fejlődés időszakában voltak aktívak (Ngn3, Mafa, Pdxl) [3-6] - de úgy tünik, ezek együttes hatására van szükség, mivel egymagukban nem elegendők [7]. A szöveti remodellálódásban egyes kísérletek szerint a pancreas csillagsejtjei is szerepet játszhatnak [8], de a Langerhans-szigetek architektúrájának kialakításában a STAT3 (signal transducer and activator of transcription 3 ) is lényeges faktor. STAT3-knockout egerekben például a kis méretű szigetek felszaporodtak a közepes méretüek rovására, ez azonban nem mutatkozott meg a hormontermelés megváltozásában [9].

A pancreas daganatai között jól ismertek, bár viszonylag ritkán fordulnak elő a kevert, neuroendokrin + nem neuroendokrin tumorok (MiNEN), de acinaris, ductalis részleteket egyaránt tartalmazó formák is előfordulnak. Húsznál is kevesebb viszont azoknak a trifázisos eseteknek a száma, melyekben acinaris, ductalis és endokrin komponens egyszerre van jelen [10-14]. Ezek között döntően malignus formák találhatók különböző agreszszivitással, de kivételesen közöltek benignus formát is [10]. Endokrin aktivitásról csak egy esetben számoltak be. Meglepő ugyanakkor, hogy a fenti szerzők közül senki nem vizsgálta a tumor körüli normális pancreasállományt, hogy vajon jelen vannak-e prekurzor laesiók, pedig elképzelhető, hogy valamilyen formában a szokásostól eltérő differenciálódás már ott is mutatkozhat.

Esetünkben malignitás a részletes feldolgozás során sem merült fel, körülírt gócos elváltozás nem alakult ki, csak a különböző irányú differenciálódás, a Langerhansszigetek hyperplasiája és atípusos megjelenése mutatkozott. Bár a szigetsejtes hyperplasia gyakori elváltozás krónikus pancreatitisben, a szövettani feldolgozás során a betegben fibrotizáló gyulladás nem volt kimutatható. Microadenomatosisnak sem felelt meg, mivel a gócok méretei 5 mm-nél kisebbek voltak. Mindamellett endokrin tünetekkel sem jártak, a kromogranin-A- és 5-HIAAszintek, valamint a szérumglükózértékek is a normálhatárokon belül maradtak. Egyetlen további endokrin szerv érintettségeként csak a pajzsmirigy korábban eltávolított follicularis adenomája említhető.

Nem tudjuk, hogy van-e kapcsolat a diffúz szigetsejtes hyperplasia, a microadenomatosis és a pancreas neuroendokrin tumorai között, mint ahogy az sem ismert, hogy ezek az endokrin tumorok prekurzor elváltozásai lennének, lévén az első két elváltozás igen ritkán előforduló entitás.

Esetünkben tehát egy különleges, komplex pancreaselváltozás állt fenn, amely a diffúz szigetsejtes hyperplasia mellett mindhárom fó sejtvonal együttesét tartalmazó gócok jelenlétével volt jellemezhető, emellett az acinusokban is neuroendokrin marker jelent meg. Hasonló esettel az irodalomban még nem találkoztunk, és a fenti folyamatok közötti esetleges kapcsolatra semmilyen információnk nincs.

Anyagi támogatás: A közlemény megírása anyagi támogatásban nem részesült.

Szerzői munkamegosztás: Z. A.: Az eset diagnosztikája, az irodalom áttekintése, a dokumentáció elkészítése, a cikk végleges formába öntése. T. J., M. K., T. M.: A beteg endokrinológiai kivizsgálása. H. G.: A beteg operációja és posztoperatív kezelése. A cikk végleges változatát valamennyi szerző elolvasta és jóváhagyta.

Érdekeltségek: A szerzőknek nincsenek érdekeltségeik.

\section{Irodalom}

[1] Pan, FC, Wright C. Pancreas organogenesis: from bud to plexus to gland. Dev Dyn. 2011; 240: 530-565.

[2] Fanjul M, Gmyr V, Sengenès C, et al. Evidence for epithelialmesenchymal transition in adult human pancreatic exocrine cells. J Histochem Cytochem. 2010; 58: 807-823.

[3] Minami K, Seino S. Pancreatic acinar-to-beta cell transdifferentiation in vitro. Front Biosci. 2008; 13: 5824-5837.

[4] Cavelti-Weder C, Li W, Weir GC, et al. Direct lineage conversion of pancreatic exocrine to endocrine beta cells in vivo with defined factors. Methods Mol Biol. 2014; 1150: 247-262.

[5] Li W, Nakanishi M, Zumsteg A, et al. In vivo reprogramming of pancreatic acinar cells to three islet endocrine subtypes. eLife 2014; 3: e01846.

[6] Lemper M, Leuckx G, Heremans Y, et al. Reprogramming of human pancreatic exocrine cells to $\beta$-like cells. Cell Death Differ. 2015; 22: 1117-1130.

[7] Xiao X, Guo P, Shiota C, et al. Neurogenin3 activation is not sufficient to direct duct-to-beta cell transdifferentiation in the adult pancreas. J Biol Chem. 2013; 288: 25297-25308.

[8] Rotti PG, Xie W, Poudel A, et al. Pancreatic and islet remodeling in cystic fibrosis transmembrane conductance regulator (CFTR) knockout ferrets. Am J Pathol. 2018; 188: 876-890.

[9] Kostromina E, Wang X, Han W. Altered islet morphology but normal islet secretory function in vitro in a mouse model with microvascular alterations in the pancreas. PLoS ONE 2013; 8: e7 1277 . 


\section{ESETISMERTETÉS}

[10] Okada Y, Mori H, Tsutsumi A. Duct-acinar-islet cell tumor of the pancreas. Pathol Int. 1995; 45: 669-676.

[11] Tanakaya K, Teramoto N, Konaga E, et al. Mixed duct-acinarislet cell tumor of the pancreas: report of a case. Surg Today 2001; 31: 177-179.

[12] Newman K, Stahl-Herz J, Kabiawu O, et al. Pancreatic carcinoma with multilineage (acinar, neuroendocrine, and ductal) differentiation. Int J Clin Exp Pathol. 2009; 2: 602-607.

[13] Stelow EB, Shaco-Levy R, Bao F, et al. Pancreatic acinar cell carcinomas with prominent ductal differentiation: mixed acinar ductal carcinoma and mixed acinar endocrine ductal carcinoma. Am J Surg Pathol. 2010; 34: 510-518.

[14] Anderson MJ, Kwong CA, Atieh M, et al. Mixed acinar-neuroendocrine-ductal carcinoma of the pancreas: a tale of three lineages. BMJ Case Rep. 2016; 2016: bcr2015213661.

(Zalatnai Attila dr., Budapest, Üllói út 26., 1085 e-mail: zalatnai.attila@med.semmelweis-univ.hu)

\section{"Necessitati sapiens nihil umquam negat." (A szükségnek mindig enged a bölcs.)}

A cikk a Creative Commons Attribution 4.0 International License (https://creativecommons.org/licenses/by/4.0/) feltételei szerint publikált Open Access közlemény, melynek szellemében a cikk bármilyen médiumban szabadon felhasználható, megosztható és újraközölhető, feltéve, hogy az eredeti szerző és a közlés helye, illetve a CC License linkje és az esetlegesen végrehajtott módosítások feltüntetésre kerülnek. (SID_1) 